Seyahat ve Otel İşletmeciliği Dergisi/

Journal of Travel and Hospitality Management

16 (2), 2019, 319-339.

Gönderim Tarihi:24.04.2019

Kabul Tarihi:29.07.2019

\title{
Doğu Akdeniz Bölgesi Dört ve Beş Yıldızlı Şehir Otellerinde İşgören Devir Hızı Üzerine Bir Araştırma
}

\section{The Employee Turnover Rate and Reasons in Four and Five Star City Hotels of East Mediterranean Region of Turkey}

Doç. Dr. Kamil UNUR

Mersin Üniversitesi

Turizm Fakültesi

E-posta: kunury@yahoo.com
Mehmet GÜNAY

Mersin Üniversitesi

Sosyal Bilimler Enstitüsü

E-posta: mehmetgunay91@hotmail.com

\author{
Prof. Dr. A. Celil ÇAKICI \\ Mersin Üniversitesi \\ Turizm Fakültesi \\ E-posta: celilcakici@mersin.edu.tr
}

\section{Öz}

Turizm Sektöründe işgören devrinin yüksek olduğuna ilişkin genel bir kabul olmasına karşın Türkiye'de konuyla ilgili yapılan araştırmalar genellikle yalnızca bir destinasyonu ya da bir ili kapsamaktadır. Bu konuda kapsamlı bilimsel veriler elde edebilmek için daha geniş alanları kapsayan çalışmalar yapılması gerekmektedir. Bu ihtiyaçtan hareketle turizm sektörünün bir parçası olan konaklama işletmelerinde yaşanan işgören devir oranı ve bu işgören devrinin nedenleri bölgesel düzeyde araştırılmıştır. Araştırma, Doğu Akdeniz Bölgesi'ndeki 4 ve 5 yıldızlı şehir otellerinde gerçekleştirilmiştir. Çalışma nicel bir araştırma olup veriler anket aracılığı ile toplanmıştır. Elde edilen veriler, analiz edilerek yorumlanmıştır. Araştırma sonuçlarında Doğu Akdeniz Bölgesi işgören devir hızının yüksek olduğu, kendi isteği ile ayrılanların ayrılma sebeplerinin ücreti yetersiz bulma ve zorunlu nedenler olduğu; yönetim tarafından çıkarılma nedenlerinin ise, işgörenin işinin gerektirdiği performansı gösterememesi ve işletme kurallarına uyulmaması olduğu belirlenmiştir. İşletmelerin işgören devrinden gördükleri zararı en aza indirmek amacıyla, işletmenin idari bölümlerine daha deneyimli işgörenleri istihdam etmeleri gerekmektedir.

Anahtar Kelimeler: Turizm, Otel, İşgören Devri, İşgören Devir Oranı, Doğu Akdeniz Bölgesi

\begin{abstract}
Although there is an agreement about the high labor turnover rate in the Tourism Sector The research done on the subject in Turkey usually only covers a destination or a province. In order to obtain comprehensive scientific data on this subject, studies covering wider areas are required. Based on this need, the rate of employee turnover experienced in hotels which are a part of the tourism sector and the reasons of this employee turnover were investigated at regional level. The study was conducted in 4 and 5 star city hotels in the Eastern Mediterranean Region. Quantitative data were collected through a questionnaire. The data obtained were analyzed and interpreted. It was found out that the turnover rate in the Eastern Mediterranean Region is high. In addition, it was determined that the reasons for leaving of the voluntarily are the insufficient salary, the obligatory reasons and the start/continue of the education. It is also found that the reasons for the termination of labor contract by the management were, not to show the performance required by the occupation, and not to obey operating rules. It may be advisable for employers to employ employees who are more experienced in the administrative departments of the business and who have worked in tourism for a long time to minimize the loss of employment.
\end{abstract}

Key Words: Tourism, Hotel, Employee Turnover, Employee Turnover Rate, East Mediterranean Region. 


\section{Giriş}

Otellerin en önemli özelliklerinden birisi emek yoğun olmaları, yani çok sayıda işgören çalıştırmalarıdır. Bu durum otellerde, insan kaynakları departmanının önemini artırımakta ve işletmenin işgücüne yönelik bakış açısını değiştirmektedir. Fakat işletme için insan faktörünün bu derece önemli olduğu bilinmesine rağmen, işletmeler kâr marjlarını yükseltmek amacıyla, işgörenlerine düşük ücretler verebilmekte, uzun saatler çalıştırabilmekte ve sosyal olanakları yeterli düzeye çıkarmamaktadır. Bu nedenlerden dolayı, işgörenlerin işletmeye olan bağlıııları azalmakta ve işletmeden ayrılmaktadır. $\mathrm{Bu}$ durumda, genel olarak işletme bünyesinde yer alan işgörenlerin, işletmeden ayrılmaları veya uzaklaştırılmaları olarak ifade edilen işgören/işgücü devri ortaya çıkmaktadır.

İşören devri, işletmeler açısından önemli bir konudur. Çünkü işgörenlerin işletmeden ayrılmalarının maliyeti tüm işgören maliyetlerinin \% 20'si civarındadır (Demarco ve Lister, 1987: 106). Reklam giderleri, işe alım süreci, işe yeni alınan işgörenlerin eğitimi, işletmeye uyumu ve ayrılan işgörenlerin kıdem tazminatları gibi somut; ayrılacak olan işgörenin verim düşüklüğü, kalanlar arasındaki moral bozukluğu gibi soyut maliyetler işletmelerin katlandığı maliyetlere örnek olarak gösterilebilir (Güzel, 2002; Gün, 2008). Söz konusu somut ve soyut maliyetler, işletme için önemli bir gider kaynağı oluşturmakta ve işletmenin piyasadaki rekabet gücünde bir düşüşe neden olmaktadır. İşletmeden ayrılan işgören, işletme için ne kadar önemli ise, bu işgörenin yerine yenisinin bulunması da bir o kadar güç hale gelecektir. Ayrıca tecrübeli bir işgören yerine alınan yeni işgörenin yeterli düzeye gelene kadar ki eğitim masrafları ve neden olduğu iş kazalarında yaşanan maddi kayıplar da işgören devrinin işletmeler için önemini arttırmaktadır (Özler, Özler ve Gümüştekin, 2007; Halis ve Çamlıbel, 2011).

İşletmenin geleceğine yönelik yapılan işgücü yatırımının, yukarıda bahsedilen negatif etkileri yaratması, işletme tarafından istenen bir durum değildir. Bu yüzden işgücü temini ve seçimi kadar, onları işletmede tutmak da önemli bir sorundur. İşletmede her işe alınan işgöreni emekli oluncaya kadar çalıştırmak, yani işgören devir hızını sıfır düzeyinde tutmak mümkün olmadığı gibi her işletme için geçerli bir standartta yoktur. Emeklilikler, ölümler, kazalar ve askerlik vb. nedenlerden dolayı mutlaka bazı işgörenler işlerini bırakmak zorunda kalacaklardır. İşgören devrinin kontrol altında tutulması işletmeye çeşitli faydalar sağlanmasında da kullanılabilir. Örneğin; düzenli olarak yeni işgörenlerin işe alınması, yeni fikirlerin oluşmasını, işletmenin ve çalışanların monotonluktan kurtulmasını sağlayabilir. Hatta işletme yeni işgöreni eskisinden daha ucuza çalıştırabilir (Güzel, 2002). Dolayısıyla işgören devir oranı yüksek olup ve devamlılık göstermediği sürece işletmeye büyük zararlar vermeyeceği söylenebilir (Tiritoğlu, 2006).

İşten ayrılma eylemi, sadece işletme açısından değil, aynı zamanda işgören açısından da olumsuz sonuçlara neden olabilmektedir. Eğer işgörenin, işletmeden ayrıldıktan sonra hemen çalışmaya başlayacağı daha iyi bir iş yoksa birey ekonomik, sosyal ve psikolojik açıdan zor durumlar yaşayabilir. İşgören herhangi bir nedenle işten ayrıldıktan sonra, yeni bir işe başlayana kadar geçen süre zarfında gelir kaybı yaşayacak ve sosyal güvencesinden mahrum kalacaktır. İşsiz kalınan süre uzadıkça yaşanan bu ekonomik durumun kişi üzerindeki baskısı daha da artar. Buna ek olarak, toplumda statü kaybı yaşayacak ve sosyal bir baskıya da maruz kalacaktır. Bu durumun uzun süre devam etmesi kişide psikolojik sıkıntılara neden olabileceği gibi, kişinin işiyle ilgili vasıflarını, bilgilerini ve yeteneklerini de kaybetmesine neden olmaktadır (Akbulut, 2008). 
Personel devir oranının belirli bir seviyede tutulabilmesi için yöneticiler öncelikle personel devrinin nedenlerini belirlemelidir. Temelde personel devrinin nedenleri işgören kaynaklı, işletme kaynaklı ve çevresel nedenler şeklinde üç başlıkta ele alınmaktadır (Güzel, 2002). İşgören kaynaklı nedenlere işgörenin başka bir işletmede, sektörde veya bölgede çalışmak istemesi, kendi işini kurması, çalışma hayatına son vermek istemesi, emeklilik, askerlik, ölüm, hastalık, hamilelik, eğitim vb. durumlar örnek gösterilebilir (Tiritoğlu, 2006). İşletme kaynaklı nedenlere; ücret miktarı, kariyer fırsatları, sosyal imkanlar, yönetimin çalışanlar üzerindeki baskısı, personel eksikliği sonucu yaşanan sıkıntılar, çalışma koşulları, stres, sosyal güvenlik vb. örnek olarak verilebilir (Pearson, 1991: 188; Tiritoğlu, 2006; Salha, 2012). İşletmenin kontrolü dışında olan ancak işgücü devrine sebep olan etkenlere talep dalgalanmaları, ekonomik daralmalar, alternatif iş olanakları, başka mesleklerin çekici hale gelmesi vb. nedenler örnek olarak verilebilir (Demir, 2002; Erbil, 2013; Saltık, 2016).

Gerek işletmeler gerekse çalışanlar açısından için bu derece önemli olan işgören devir hızının ne olduğu ve bu devrin nedenlerinin neler olabileceğinin araştırılması gerekmektedir. Alanyazında daha önce yapılan çalışmaların yalnızca destinasyon ve iller bazında yapıldığı bölgesel ve tüm ülkeyi kapsayan bir çalışma yapılmadığı görülmüştür. Bu nedenle çalışmanın temel amacı, Doğu Akdeniz Bölgesi'nde faaliyet gösteren 4 ve 5 yıldızlı şehir otellerinde yaşanan işgören devir oranlarının saptanması ve işgücü devrinin nedenlerinin tespit edilmesidir.

Bu çalışmada parçadan bütüne gidilerek, Doğu Akdeniz Bölgesinde ve diğer illerde yapılan çalışmaların, işgücü devri için izlenmesi gereken politika ve önerilerin belirlenmesine katkı sağlayacağı düşünülmektedir. Ayrıca yüksek işgören devrinin, istenilen düzeye indirilmesi gereğinin ortaya konulması, konuyla ilgili istatistiki bilgilere sahip olunması, turizm endüstrisi profesyonellerine bilgi ve uygulama anlamında önemli katkılar sağlayacaktır.

\section{Literatür}

Türkiye'de ve dünyada özellikle 4 ve 5 yıldızlı oteller olmak üzere turizm işletmelerinde yaşanan iş gören devrinin tespitine yönelik çok sayıda çalışma yapıımıştır. Ancak bu çalışmaların tamamı bir destinasyonu ya da en fazla iki destinasyonu hedef alan çalışmalardır. Kuşadası'ndaki dört ve beş yıldızı otel işletmelerinde işgören devir hızı \%40-50 aralığında ve İzmir merkezdeki dört ve beş yıldızlı otellerdeki işgören devri \%10-20 olarak (Güzel, 2002), Ankara'daki yıldızlı otellerde işgören devir hızı ortalaması \% 34 olarak bulunmuştur. Yıldız sayılarına göre yapılan değerlendirmede, en düşük personel devir oranının beş yıldızlı otel işletmelerinde yaşandığı tespit edilmiştir (Tuna, 2007). Sarıoğlan'da (2007) benzer bir sonuca ulaşarak yıldız sayısı yüksek olan otellerin personel devir oranın düşük, yıldız sayısı düşük olan otellerin ise, personel devir oranının yüksek olduğunu söylemektedir. Kapadokya'da yapılan bir araştırmada işgücü devir oranı Nevşehir Şehir Merkezi'nde \% 49,50, Ürgüp'te \% 43,7, Göreme'de \% 36,22, Avanos' ta \% 38,89 olarak ve bölge ortalaması ise \%46.08 olarak hesaplanmıştır (Gün, 2008). Aynı bölgede farklı otellerde farklı yıllarda yapılan araştırmalarda farklı işgören devir oranları hesaplanmıştır. Örneğin Antalya yöresinde bulunan 12 ay hizmet veren 5 yıldızıı 7 otelin işgören devri ortalaması \%67.02 olarak (Bozkurt, 2010) bulunurken bir başka çalışmada Antalya'da faaliyet gösteren beş yıldızlı otellerdeki işgören devir oranının \%39 olduğu ve en yüksek devrin kasım ayında gerçekleştiği tespit edilmiştir (Aksu, 1995). Muğla bölgesinde faaliyet gösteren 4 ve 5 yıldızlı oteller ile 1. ve 2. sınıf tatil köylerinde işgücü devir oranın $\% 49,79$ olduğu ve en yüksek devrin yiyecek-içecek bölümünde, en düşük devrin ise muhasebe bölümünde gerçekleştiği belirlenmiştir (Demir, 2002). Ayrıca Muğla bölgesindeki turizm merkezleri 
arasında en yüksek işgücü devir oranının Bodrum'da, en düşük oranın ise SarıgermeDalyan'da olduğu sonucuna ulaşılmıştır (Demir, 2002). Yapılan bir çalışmada otellerde iş gören devrinin kat hizmetleri departmanında en düşük ve yiyecek-içecek departmanında ise en yüksek olduğu belirlenmiştir (Akova, Tanrıverdi ve Kahraman, 2015) Bir başka çalışmada ise personel devrinin çoğunlukla operasyonel (önbüro, yiyecek içecek ve housekeeping) departmanlarda gerçekleştiği belirlenmiştir (Chalkiti ve Sigala, 2010). İngiltere'de deniz kıyısında yer alan Torbay beldesindeki konaklama işletmelerinde işten ayrılma oranlarının ortalama olarak \%69 olduğu ve işin türüne ve büyüklüğüne bağlı olarak ayrılma oranlarının değiştiği, Avustralya'da faaliyet gösteren dört ve beş yıldızlı otellerde çalışanlar ve idari personel için yıllık ayrılma oranının sırasıyla \%50,74 ve \%39.19 olduğu belirlenmiştir (Davidson, Timo ve Wang, 2010).

Yüksek İşücü devrinin çeşitli nedenleri vardır ve bu nedenler araştırmalarla ortaya konulmuştur. Araştırmalarda genel olarak; ücret yetersizliği (Pizam ve Thornburg 2000; Güzel, 2002;, Demir, 2002; Wamsley, 2004; Chalkiti ve Sigala, 2010), ödemelerin zamanında yapılmaması (Aksu, 1995), zorunlu nedenler, iş tatminsizliği (Aksu, 1995; Pizam ve Thornburg, 2000; Güzel, 2002; Wamsley, 2004; Dusek, Clarke, Yurova ve Ruppel, 2016), yönetim şekli, çalışma saatleri (Demir, 2002; Akova, Tanrıverdi ve Kahraman, 2015; Ezeuduji ve Mbane, 2017), stres, ülkedeki ekonomik durum, iş bulma imkanları (Tiritoğlu, 2006; Pizam ve Thornburg 2000), aile yükümlülükleri (Pizam ve Thornburg 2000; Chalkiti ve Sigala, 2010), hizmet süresi (Pizam ve Thornburg 2000; Akova, Tanrıverdi ve Kahraman, 2015; Ezeuduji ve Mbane, 2017), beklentilerin karşılanmaması, yaş, iş arkadaşlarıyla ilişkilerin kalitesi, personel yönetiminde maliyet odaklı bir yaklaşım benimsenmesi, işletmenin net olmayan beklentileri, işe alım ve performans değerlendirme yöntemlerinin yetersizliği, (Pizam ve Thornburg, 2000) makro çevre faktörleri (Sarıoğlan, 2007) oryantasyon eğitimi verilmemesi, yazılı iş tanımlarının bulunmaması (Tuna, 2007), yasal olarak hak edilen haklardan yararlanamama, izin günlerini kullanamama, işletmelerin bilgi alışverişi konusunda şeffaf olmaması (Aksu, 1995) mevsimsellik (Chalkiti ve Sigala, 2010) işgörenlerin sahip oldukları eğitim alanı ile çalıştıkları işin gerektirdiği eğitim alanının uyumsuzluğu, çalışanların eğitim düzeyi ve nitelikleri ile çalıştıkları işin gerektirdiği eğitim düzeyi ve niteliklerinin uyumsuzluğu, (Kazak, 2012), işletmenin yapısı, işyerinde çalışılan departman, statü (Akova vd, 2015), kariyer fırsatlarının olmayışı ve kötü çalışma ortamı (Ezeuduji ve Mbane'nin (2017) gibi faktörler yüksek işgücü devrinin nedenleri olarak ortaya konmuştur. Yukarıda sayılan tüm nedenleri Yang, Wan ve Fu, (2012) işletme kaynaklı nedenler, maaş ve kazanımlar, duygusal durumlar, endüstrinin çalışma tarzı ve sorumluluklar ve çalışma ortamı şeklinde beş başık altında toplamıştır.

Bu derece yüksek olan işgücü devri işletmelere ciddi bir maliyet yüklemektedir. Aksu (1995) İşgörenlerin işten ayrılmalarının işletmeye maliyetini; işgörenin işten ayrılma maliyeti, yeni işgörenin işe alınması ve işgören eğitimi olmak üzere 3 başlık altında toplamaktadır. Pizam ve Thornburg (2000) bu maliyetlere seçilen personelin ayrılan kişiye eşdeğer performans düzeyine ulaşıncaya kadar müşteri memnuniyetinde yaşanacak düşüşü ve işletme karlılığında oluşacak azalmayı da eklemektedir. Bozkurt (2010) bir yıldır görev yapan bir kat hizmetleri şefinin işten ayrılmasıyla, yerine yeni işgören alınması da dâhil olmak üzere işletmeye yüklenen toplam maliyeti 3952,31 TL olarak hesaplamıştır. Davidson, Timo ve Wang (2010) yalnızca somut maliyetleri de göz önüne alındığında bir otelin her yıl yönetici ve uzman personel yerine geçen yeni bir çalışan için 109.909 ABD Doları, normal statüde bir personelin değiştirilmesi için ise ortalama 9,591 ABD doları harcadığını ve somut olmayan maliyetler dahil edildiğinde bu rakamların daha da artacağını söylemektedir. 
İşletmeler sürekli olarak kariyer gelişimi ve eğitim yoluyla sadık ve yetenekli çalışanları daha uzun süre işletmede tutmaya çalışarak yeni çalışanların işe alınması ve geliştirilmesi için gereken ek maliyetleri azaltılabilir (Ezeuduji ve Mbane'nin, 2017).

İşgücü devrinin azaltılmasında yönetim kademelerinde çalışanlar çok önemlidir. Bu nedenle yönetici seçimi yapılırken, sorumlu olacağı tüm aşamalar hakkında tecrübe ve bilgi birikimine sahip adayların seçilmesi çok önemlidir. (Ongori, 2007). Ayrıca işe alınan yöneticilerin personel seçim sürecini daha etkin bir şekilde yürütmelerine yardımcı olacak, cinsel taciz, işgücü çeşitliliği ve çalışan disiplini gibi konularla başa çıkabilmesi için işyeri zorluklarının farkındalığını artıracak, yeni çalışanların işle ilgili özelliklerini, güçlü ve zayıf yönlerini analiz edebilmeleri ve yeni çalışanların özelliklerine uygun işlerle eşleştirebilmeleri için ve iyi bir çalışan performans değerlendirme sistemi kurulmasına yönelik eğitimler verilmelidir (Choi ve Dickson, 2009).

Alanyazın genel olarak değerlendirildiğinde, otellerde yaşanan iş gören devir hızlarıyla ilgili çok farklı rakamların olduğu görülmektedir. Bu farklılıkların temel olarak çalışmaların bazılarının şehir otellerinde bazılarının ise kıyı otellerinde yapılmış olmasından kaynaklandığı düşünülmektedir. Ayrıca çalışma yapılan otellerin yıldız sayılarındaki farklılıkların da sonuçların farkılaşmasına yol açtığı görülmektedir. Yine alanyazında görüldüğü gibi Türkiye'de yapılan çalışmalar dar kapsamlı olup destinasyon ve il bazında yapılmıştır. Gerek çalışmalardaki işgücü devir oranı farklılıkları, gerekse çalışmaların çok dar alanlarda yapılmış olması bu konuda daha kapsamlı çalışmalar yapılması gerekliliğini ortaya çıkarmaktadır.

\section{Araştırmanın Problemi}

Alanyazın incelendiğinde Doğu Akdeniz Bölgesi'nden herhangi bir çalışmanın yapılmadığı görülmüştür. Bu yüzden araştırma, Doğu Akdeniz Bölgesi için ilk olma niteliği taşımaktadır. İşgücü devri ve işgücü devir oranı anahtar kelimeleri kullanılarak, Türkçe literatürde, Ocak 2016 ile Şubat 2018 tarihleri arasında internet üzerinde yapılan aramalarda, konaklama işletmeleriyle ilgili olan 12 makaleye yine aynı tarihlerde YÖK Ulusal tez merkezinde yapılan taramada 11 yüksek lisans tezi olduğu görülmüştür. Aynı tarihlerde staff turnover, employee turnover kelimeleriyle Ingilizce literatürde yapılan taramada konaklama işletmeleriyle ilgili 14 adet çalışmaya rastlanılmıştır. Ulaşılan çalışmaların hiç birisinin Doğu Akdeniz Bölgesinde yapılmamış olması ve Türkiye genelini kapsayan bir çalışma olmaması nedeniyle bu çalışmanın yapılmasına karar verilmiştir.

\section{Araştırmanın Yöntemi}

Araştırmanın uygulama alanı, yani araştırmanın çalışma grubu Doğu Akdeniz Bölgesi'nde faaliyet gösteren dört ve beş yıldızlı şehir otelleridir. Araştırmaya dahil edilecek otellerin bilgileri, faaliyet gösterdikleri şehirlerin İ Kültür ve Turizm Müdürlüklerinden e-posta yoluyla veya internet sitelerinden elde edilmiştir. Bölgede toplam 48 adet 4-5 yıldızlı şehir oteli olduğu belirlenmiştir. Araştırmada örneklem almak yerine tamsayım hedeflenmiş ve 29 'u dört ve 11 'i beş yıldız olmak üzere toplam 40 otelden veri toplanmıştır. Bu rakamlar ana kütlenin \%83'ünü temsil etmektedir. Araştırmaya katılan otellerin 19`u Adana'da, 10'u Mersin'de, 6'sı Hatay'da, 1'i Osmaniye'de ve 4 adedi de Kahramanmaraş'ta yer almaktadır.

Veriler, araştırma kapsamında Doğu Akdeniz Bölgesi'nde araştırmada yer almak isteyen tüm dört ve beş yıldızlı otellerden anket yoluyla yüz yüze görüşülerek toplanmıştır. İşgücü devrinin tespiti ve işgücü devrine neden olan unsurları belirlemek 
için, daha önce Güzel (2002), Demir (2002), Gün (2008) ve Bozkurt (2010) tarafından kullanılan soru formlarından yararlanılmıştır. Araştırmaya katılan otel işletmelerinden ayrılan işgörenlerin bulunması ve ayrılma nedenlerine yönelik verilerin elde edilmesinin imkânsızlığı nedeniyle, anket sorularını özellikle insan kaynaklarından sorumlu yöneticilerin doldurması istenilmiştir. İnsan kaynakları departmanının bulunmadığı işletmelerde ise genel müdür, muhasebe departmanı ve önbüro müdürü ile görüşülmüştür Anket üç tanesi anketi dolduran kişiye, üç tanesi ankete konu işletmeye ve 16 tanesi ise personel devrine ilişkin olmak üzere toplam 22 sorudan oluşmaktadır.

İşücü devir oranını hesaplamak için kullanılan yöntemlerden biri olan, işgücü akış yönteminin ikinci durum formülü kullanılmıştır. Girişlere ve çıkışlara göre hesaplanan formülden farklı olarak, bu formülde hem ayrılmalar hem de girişler işleme dahil edilmektedir. Formül, belirli bir dönem içindeki işgören devrinin bulunmasında kullanılmaktadır. Birinci formülün eksikliği; işe alınan ve işten ayrılan işgörenlerin toplamı alındığı için, sayıca yaklaşık iki kat daha fazla çıkmasına sebep olmaktadır. Gelişme aşamasındaki işletmeler için bu formül yanlış sonuçlar verebilmektedir. İkinci formülde ise, işten ayrılanların ve işe girenlerin sayıları toplanır ve ikiye bölünür. Böylece, ilk formüldeki yüksek işgören devri yarıya inmiş olur. Yüzdelik oranı hesaplamak için ise, çıkan sonuç yüzle çarpılır (Kaynak, 1990: 44). Formül aşağıdaki gibidir;

İşe alınan + işten ayrılan işgören sayısı

İşgören Devir Oranı =

2

Ortalama is gören sayısı

$x 100$

\section{Bulgular ve Değerlendirme}

Çalışmaya katılan yöneticilerin \%45'ini genel müdürler, \%23'ünü muhasebe, \%20'sini insan kaynakları ve \%12'sini ise önbüro müdürleri oluşturmaktadır. Yöneticilerin çalışma sürelerine bakıldığında, \%5'inin bir yıldan az, \%22'sinin 1-2 yıl, \%33'ünün 3-5 yıl, \%28'inin 6-10 yıl ve \%12'sinin 11-15 yıl aralığında aynı işletmede çalıştıkları belirlenmiştir. Araştırmaya katılan yöneticilere turizm sektöründeki çalışma süreleri de sorulmuştur. Verilen cevaplar doğrultusunda yöneticilerin ortalama 13 yıl 4 aydır sektörde olduğu bilgisine ulaşılmıştır. Verilen cevaplar arasında sektörde en çok 30 yıl en az ise 6 ay çalışan yöneticiler olduğu görülmüştür.

Araştırmaya katılan 40 işletmenin 29'u (\%72,5) 4 yıldızlı, $11^{\prime} i$ ise $(\% 27,5)$ de 5 yıldızlıdır. İşletmelerin 26 tanesi (\%65) bağımsız otel, 9 tanesi $(\% 22,5)$ zincir otel ve 5 tanesi $(\% 12,5)$ ise grup oteldir.

Ankette yer alan "Işsletmenizde herhangi bir sendika faaliyet gösteriyor mu?" sorusuna, sadece 1 işletme evet cevabı vermiştir. Bu sonuç Türkiye'deki sendikalı işçi sayısının azalmasıyla paralellik göstermektedir. Tüm Türkiye'de kayıt dışı çalışanlar hariç konaklama ve eğlence sektöründe 2016 yılı verilerine göre 794.739 turizm çalışanı bulunmaktadır. Bunların sadece 31.213'ü sendikalıdır (www.csgb.gov.tr, 2019). Ayrıca görüşülen otel işletmelerinin 26 tanesinde (\%65) insan kaynakları planlaması yapılmadığı yalnızca 14 tanesinde (\%35) yapıldığı belirlenmiştir.

İşletmelerin 17 tanesi $(\% 42,5)$ bünyelerinde yaşanan personel devrini hiçbir zaman dikkate almadıklarını belirtmiştir. Personel devir oranını dikkate alan işletmelerin daha çok insan kaynakları planlaması yapan işletmeler olduğu görülmüştür. Araştırmaya katılan otel işletmelerinin 13'ü insan kaynakları planlaması yaptığını ve personel devir oranını her zaman dikkate aldığını belirtmiştir. 10 işletme 
insan kaynakları planlaması yapmadığı halde personel devir oranını her zaman dikkate aldığını, 1 işletme ise insan kaynakları planlaması yaptığı halde personel devir oranını dikkate almadığını belirtmiştir. Geriye kalan 16 işletme ise insan kaynakları planlaması yapmadığını ve aynı zamanda personel devir oranını dikkate almadığını belirtmiştir.

Personel devir oranını hesaplayan işletmeler toplam işletmelerin \%25'ini oluşturmaktadır. Personel devir oranını dikkate alan işletmelerden yalnız 9'u personel devir oranını hesapladıklarını, geri kalan 14'ü ise personel devrini dikkate aldıklarını fakat personel devir oranını hesaplamadıklarını ifade etmişlerdir. Bir işletme personel devir oranını dikkate almadıkları halde devir oranını hesapladıklarını, geriye kalan 16 işletme ise hem personel devir oranını dikkate almadıklarını, hem de devir oranını hesaplamadıklarını belirtmiştir.

Personel devir oranını hesaplayan ve hesaplamayan işletmelerin, işletmelerinde gerçeklesen personel devir oranını tahmini olarak yazmaları istenmiştir. Verilen bilgiler doğrultusunda işletmelerin $\% 85$ 'i bünyelerinde gerçeklesen personel devir oranının $\% 30$ ve altında olduğunu belirtmiştir. Tablo 1'de bu tahminlerin 4 ve 5 yıldızlı işletmelerde nasıl bir dağılım gösterdiği görülmektedir. Yöneticilerin tahmini cevaplarının ortalaması alındığında, yöneticiler, 4 yıldızlı işletmelerde ortalama \% 18,5, 5 yıldızlı işletmelerde ise \%21,1 oranında bir devir gerçekleştiğini belirtmiştir.

Tablo 1: Yıldıza Göre Tahmini Personel Devir Oranının Dağıımı

\begin{tabular}{|l|c|c|c|c|c|c|}
\hline \multirow{2}{*}{ Tahmini PDO } & \multicolumn{3}{|c|}{ 4 Yıldızlı } & \multicolumn{3}{c|}{5 Yıldızlı } \\
\cline { 2 - 7 } & Frekans & Yüzde & $\begin{array}{l}\text { Birikimli } \\
\text { Yüzde }\end{array}$ & Frekans & Yüzde & $\begin{array}{l}\text { Birikimli } \\
\text { Yüzde }\end{array}$ \\
\hline \% 5 den az & 5 & 17,2 & 17,2 & - & - & - \\
\hline$\%$ 5-10 arası & 2 & 6,9 & 24,1 & 1 & 9,1 & 9,1 \\
\hline$\% 11-20$ arası & 8 & 27,6 & 51,7 & 5 & 45,5 & 54,5 \\
\hline$\%$ 21- 30 arası & 10 & 34,5 & 86,2 & 3 & 27,3 & 81,8 \\
\hline$\%$ 31- 40 arası & 4 & 13,8 & 100,0 & 1 & 9,1 & 90,9 \\
\hline$\%$ 41- 50 arası & - & - & - & 1 & 9,1 & 100,0 \\
\hline Toplam & 29 & 100,0 & & 11 & 100,0 & \\
\hline
\end{tabular}

Katılımcı işletmelere geçen yıllara göre personel devir oranında herhangi bir artma ya da azalma olup olmadığı, nedeniyle birlikte sorulmuştur. İşletmelerin \% 45 'i (18 otel) personel devir oranının geçen yıllara göre arttığını belirtmiştir. Bu 18 işletmenin 12'si yaşanan bu artışın sebeplerini ülkede yaşanan terör olayları ve patlamalar, Rusya ile yaşanan uçak krizi, 15 Temmuz 2015 darbe girişimi ve ülkede yaşanan ekonomik kriz şeklinde sıralamıştır. Bahsi geçen bu olaylar nedeniyle ülkeye gelen turist ve iş adamı sayılarında ciddi azalmalar olduğu, bundan dolayı da mevcut personelde azaltmaya gidildiği ya da tekrardan maaş düzenlemesi yapıldığı yine ifadeler arasındadır. 2 işletme ise kalifiye eleman sıkıntısı olduğunu ve iş potansiyelinin artmasından dolayı devir oranında artış yaşandığını belirtmiştir. 2 işletme, artık personel intiyaçlarının değiştiğini, ücretler ve çalışma koşulları konusunda insanların daha seçici olduğunu, buna bağlı olarak da işletmeden ayrılmaların arttığını belirtmiştir.

Personel devir oranında azalma olduğunu söyleyen işletmeler \%25 oranındadır. $\mathrm{Bu}$ oranı 10 işletme oluşturmakta ve bu işletmelerin $5^{\prime} \mathrm{i}$ personel devir oranındaki azalmanın ülkede yaşanan terör olaylarından dolayı gelen müşteri sayısındaki 
azalmalara bağlı olarak daha az personel çalıştırma, ekonomi ve ülkenin gelecekteki durumu hakkındaki belirsizlikten dolayı çalışanların işsiz kalma korkusu yaşamasından kaynaklandığını belirtmiştir. 3 işletme, bünyelerinde çalışan personelin kadrolu olduğunu, işletmenin çalışma koşulları ve personele sunduğu imkanlarda iyileştirme yapıldığını, bunun neticesinde de personel devrinde azalma yaşandığını belirtmiştir. 2 işletme ise personel seçiminde titiz davrandıklarını, personelin sosyal haklarını korumak ve onları işletmede tutmak için önlemler aldıklarını, sürekli eğitim ve motivasyon toplantıları yaptıklarını ve bu sayede personel devir oranında azalma yaşadıklarını ifade etmiştir.

Tablo 2: Önceki Yıllara Oranla Personel Devir Oranının Gelişimi

\begin{tabular}{|l|c|c|c|c|}
\hline \multicolumn{1}{|c|}{$\begin{array}{c}\text { PDO Önceki yıllara } \\
\text { oranla...? }\end{array}$} & 4 Yıldızlı & 5 Yıldızlı & Toplam Frekans & Yüzde \\
\hline Artmıştır & 12 & 6 & 18 & 45,0 \\
\hline Azalmıştır & 8 & 2 & 10 & 25,0 \\
\hline Bir değişiklik olmamıştır & 9 & 3 & 12 & 30,0 \\
\hline Toplam & 29 & 11 & 40 & 100,0 \\
\hline
\end{tabular}

Gerçekleşen bu devir oranı gönüllü ayrılmalar ve yönetim tarafından çıkarmalar olarak ikiye ayrılabilir. Yöneticilerin büyük çoğunluğu, ayrılan işgörenlerin kendi isteğiyle ayrıldığını ifade etmiştir. Tablo 3'de, kendi isteğiyle ayrılma oranlarında en çok tekrarlanan değerin \%70-80 (23 işletme) olduğu görülmektedir. Kendi isteği ile ayrılan işgörenler, toplam ayrılan işgörenlerin \%79'unu oluşturmaktadır.

Tablo 3: İşten Ayrılma ve İşten Çıkarma Oranları

\begin{tabular}{|c|c|c|c|c|c|}
\hline \multicolumn{3}{|c|}{ Kendi isteğiyle ayrılma oranları } & \multicolumn{3}{|c|}{ Yönetim tarafından çıkarılma oranları } \\
\hline Yüzde & Frekans (işletme) & Ortalama & Yüzde & Frekans (işletme) & Ortalama \\
\hline 50.00 & 1 & \multirow{9}{*}{$\% 79$} & 3.00 & 1 & \multirow{9}{*}{$\% 21$} \\
\hline 60.00 & 3 & & 5.00 & 4 & \\
\hline 70.00 & 11 & & 10.00 & 6 & \\
\hline 80.00 & 12 & & 15.00 & 2 & \\
\hline 85.00 & 2 & & 20.00 & 12 & \\
\hline 90.00 & 6 & & 30.00 & 11 & \\
\hline 95.00 & 4 & & 40.00 & 3 & \\
\hline 97.00 & 1 & & 50.00 & 1 & \\
\hline Total & 40 & & Total & 40 & \\
\hline
\end{tabular}

Her ayrılan personelin işletmeye aynı derecede etki etmeyeceği, kalifiye personelin yerini doldurmanın zor olduğu bilinmektedir. Bu bilgiye dayanarak işletmelere ayrılan personelin performans düzeyleri sorulmuştur. İşletmelerden 22'si ayrılanların kalanlardan daha düşük performansa sahip olduklarını belirtmiştir. Bazı işletmeler, ayrılan işgörenlerin bu performans düşüklükleri nedeniyle işletmeye ayak 
uyduramadıklarını bu sebepten dolayı da personel devrini arttırdıklarını da eklemiştir. Geriye kalan 18 işletme ise ayrılan personelin kalanlardan bir farkı olmadığını, hepsinin aynı performansa sahip olduğunu ifade etmiştir.

Çalışanlar çeşitli sebeplerden dolayı kendileri işten ayrılmakta ya da yönetim tarafından işten çıkarılmaktadır. Bazı ayrılma sebepleri ortadan kaldırılarak ayrımaların önüne geçilebilirken bazı sebepler ve ayrılmalara ise müdahale edilememektedir. Çalışanların kendi isteği ile ayrılma sebepleri incelendiğinde büyük bir çoğunluğun (\%75) aldığı ücreti yetersiz görmesinden dolayı ayrıldığı bilgisine ulaşılmıştır. İşletmelerin $\% 77,5^{\prime} \mathrm{i}$ yani 40 işletmenin $31^{\prime} \mathrm{i}$, çalışanlarının ücreti yetersiz bulmasından dolayı işletmeden ayrıldığını belirtmiştir. Ülkede yaşanan krizlerin ve artan enflasyon oranının, bu maddenin daha öne çıkmasına neden olduğu düşünülmektedir.

Zorunlu nedenlerden dolayı işgörenlerinin ayrıldığını belirten işletme sayısı ise 20 'dir. Zorunlu nedenlerin başında askerlik ve evlilik yer almaktadır. Araştırmaya katılan yöneticiler, genellikle kadın çalışanların evlendikten sonra işten ayrıldığını, erkeklerin ise işe devam ettiklerini belirtmiştir.

Tablo 4: Kendi İstekleriyle İşten Ayrılan İşgörenlerin Ayrılma Sebepleri

\begin{tabular}{|c|c|c|c|c|c|}
\hline $\begin{array}{l}\text { Kendi istekleriyle ayrılanların } \\
\text { ayrılma sebepleri }\end{array}$ & $\begin{array}{c}4 \\
\text { Yıldızlı }\end{array}$ & $\begin{array}{c}5 \\
\text { Yıldızlı }\end{array}$ & Frekans & $\begin{array}{r}\text { İşletmelerin } \\
\text { Yüzdesi* }\end{array}$ & $\begin{array}{r}\text { Maddelerin } \\
\text { yüzdesi }\end{array}$ \\
\hline Aldığı ücreti yetersiz görmesi & 21 & 10 & 31 & 77,5 & 22,8 \\
\hline $\begin{array}{l}\text { Zorunlu nedenler (evlilik, askerlik, } \\
\text { sakatlanma) }\end{array}$ & 16 & 4 & 20 & 50,0 & 14,7 \\
\hline Turizmde yaşanan istikrarsızlık & 13 & 4 & 17 & 42,5 & 12,5 \\
\hline Eğitime başlama / devam etme & 8 & 5 & 13 & 32,5 & 9,5 \\
\hline Yaptığı iştenduyduğutatminsizlik & 7 & 5 & 12 & 30,0 & 8,8 \\
\hline Aşırı stres & 9 & - & 9 & 22,5 & 6,7 \\
\hline Kendi işini kurmaya karar verme & 5 & 3 & 8 & 20,0 & 5,9 \\
\hline $\begin{array}{l}\text { Sunulan sosyal olanakların } \\
\text { yetersiz gelmesi }\end{array}$ & 7 & - & 7 & 17,5 & 5,1 \\
\hline $\begin{array}{l}\text { Yöneticilerin turizm bilincinin } \\
\text { olmaması }\end{array}$ & 6 & 1 & 7 & 17,5 & 5,1 \\
\hline $\begin{array}{l}\text { İşyerinde terfi olanaklarının } \\
\text { olmaması }\end{array}$ & 4 & 2 & 6 & 15,0 & 4,4 \\
\hline İşletmenin el değiştirmesi & 1 & 1 & 2 & 5,0 & 1,5 \\
\hline $\begin{array}{l}\text { İşyerindeki çalışma koşullarının } \\
\text { yetersiz olması }\end{array}$ & 2 & - & 2 & 5,0 & 1,5 \\
\hline $\begin{array}{l}\text { Yönetimin personeli motive } \\
\text { edememesi }\end{array}$ & 1 & - & 1 & 2,5 & 0,7 \\
\hline İşverenle anlaşmazlık yaşaması & 1 & - & 1 & 2,5 & 0,7 \\
\hline
\end{tabular}

*: Birden fazla seçenek işaretlendiği için yüzdelik toplam yüzde yüzü aşmaktadır. 
Yönetim tarafından çalışanların işten çıkarma nedenlerine bakıldığında en yaygın nedenin yöneticilerine göre işgörenlerin işin gerektirdiği performansı gösterememesi olduğu görülmektedir (Tablo 5). Araştırmaya katılan 40 işletmeden 38'i aynı görüştedir.

Tablo 5: Yönetim Tarafından İşten Çıkarılan Kişilerin Çıkarılma Nedenleri

\begin{tabular}{|l|c|c|c|c|c|}
\hline $\begin{array}{l}\text { Yönetim tarafından işten } \\
\text { çıkarılan kişilerin çıkarılma } \\
\text { nedenleri }\end{array}$ & $\begin{array}{c}\mathbf{4} \\
\text { Yıldızlı }\end{array}$ & $\begin{array}{c}\mathbf{5} \\
\text { Yıldızlı }\end{array}$ & Frekans & $\begin{array}{c}\text { İşletmelerin } \\
\text { Yüzdesi }\end{array}$ & $\begin{array}{c}\text { Maddelerin } \\
\text { yüzdesi }\end{array}$ \\
\hline $\begin{array}{l}\text { İşinin gerektirdiği performansı } \\
\text { gösterememesi }\end{array}$ & 27 & 11 & 38 & 95 & 37,25 \\
\hline İşletme kurallarına uyulmaması & 24 & 9 & 33 & $\begin{array}{c}82, \\
5\end{array}$ & 32,35 \\
\hline $\begin{array}{l}\text { İ̧̧letmedeki satışların } \\
\text { azalması veya küçülmesi } \\
\text { sonucupersonel fazlalığının } \\
\text { oluşması }\end{array}$ & 12 & 6 & 18 & 45 & 17,65 \\
\hline $\begin{array}{l}\text { İş arkadaşları ile anlaşamama } \\
\text { Sözleşmenin sona ermesi }\end{array}$ & 1 & 2 & 10 & 25 & 9,80 \\
\hline
\end{tabular}

*: Birden fazla seçenek işaretlendiği için yüzdelik toplam yüzde yüzü aşmaktadır.

Yönetimin ve işgörenin müdahale edemediği ama işgücü devrine neden olan durumlar Tablo 6'da verilmektedir. Müdahale edilemeyen sebepler arasında ilk sırayı, ülkede yaşanan ekonomik krizler sonucu yaşanan işgören devri almıştır. Bu seçenek, çalışmaya katılan 40 işletmenin 29'u $(\% 72,5)$ tarafından işaretlenmiştir.

Tablo 6: Personel Devrine İşletme ve İşgörenin Müdahale Edemediği Durumlar

\begin{tabular}{|l|c|c|c|}
\hline $\begin{array}{c}\text { Elinizde olmadan hangi nedenlerden dolayı } \\
\text { personel devri yaşamaktasınız? }\end{array}$ & Frekans & $\begin{array}{c}\text { Işletmelerin } \\
\text { Yüzdesi }^{*}\end{array}$ & $\begin{array}{c}\text { Maddelerin } \\
\text { yüzdesi }\end{array}$ \\
\hline Ülkede yaşanan ekonomik krizler & 29 & 72,5 & 31,9 \\
\hline İşletme müşterilerinde meydana gelen azalmalar & 25 & 62,5 & 27,5 \\
\hline Başka mesleklerin bireye çekici hale gelmesi & 16 & 40,0 & 17,6 \\
\hline Mevsimsel dalgalanmalar & 15 & 37,5 & 16,5 \\
\hline İşsizlik oranının düşük olduğu dönemler & 5 & 12,5 & 5,5 \\
\hline $\begin{array}{l}\text { Ucuziş gücüolmasınedeniyleSuriyeli } \\
\text { mültecileri çalıştırmak }\end{array}$ & 1 & 2,5 & 1,1 \\
\hline
\end{tabular}

*: Birden fazla seçenek işaretlendiği için yüzdelik toplam yüzde yüzü aşmaktadır.

$\mathrm{Bu}$ araştırmaya katılan işletmeler, ayrılan personelin işletmeye en çok kıdem tazminatı konusunda maliyet yüklediğini belirtmiştir. Oysa Türkiye İşveren Sendikaları Konfederasyonu'nun (TiSK) her yıl yayımladığı Çalışma İstatistikleri ve İşücü Maliyeti İstatistiklerinde, kıdem tazminatının, toplam işgücü maliyetinde yalnızca \% 4,4'lük bir yer kapladığı görülmüştür (TiSK, 2017). 
Tablo 7: İşten Ayrılmaların İşletmeye Yüklediği Maliyetler

\begin{tabular}{|l|c|c|c|}
\hline $\begin{array}{c}\text { 2016 döneminde işletmeden ayrılanlar } \\
\text { işletmeye ne tür maliyetler yükledi? }\end{array}$ & Frekans & $\begin{array}{c}\text { Işletmelerin } \\
\text { Yüzdesi }^{*}\end{array}$ & $\begin{array}{c}\text { Maddelerin } \\
\text { yüzdesi }\end{array}$ \\
\hline Kıdem tazminatı & 34 & 85 & 28,6 \\
\hline Yeni alınanın uyum sorunları & 32 & 80 & 26,9 \\
\hline Yeni personel bulmak için reklam giderleri & 23 & 57,5 & 19,3 \\
\hline Eğitim masrafları & 12 & 30 & 10,1 \\
\hline Verimin azalması & 9 & 22,5 & 7,6 \\
\hline Kalan çalışanlar arasında verim düşüklüğü & 6 & 15 & 5,0 \\
\hline Kazaların artması & 2 & 5 & 1,7 \\
\hline Başvuru formlarının basılması & 1 & 2,5 & 0,8 \\
\hline
\end{tabular}

*: Birden fazla seçenek işaretlendiği için yüzdelik toplam yüzde yüzü aşmaktadır.

Araştırmaya katılan yöneticilere personelin ayrılmasına yönelik ne tür önlemler aldıkları sorulmuştur. İşletmelerden 15 'i ayrılan personel için herhangi bir önlem almadıklarını ifade etmişlerdir. Geriye kalan $25^{\prime} i$ ise aldıkları önlemleri sıralamışlardır. Elde edilen cevaplar içerik analizine tabi tutularak, aynı ya da birbirine yakın cevaplar bir başlık altında toplanmış olup, ortaya çıkan başlıklar Tablo 8'de sıralanmıştır.

Elde edilen cevaplar neticesinde işletmelerin çoğunluğu, işgörenlerin işten ayrılmasını önlemek için motivasyon görüşmeleri yaptığını belirtmiştir. Önlem alan 25 işletmenin 12'si bu önlemi aldığını ifade etmiştir. Maaş düzenlemesinin ise motivasyon görüşmesinden sonra en sık başvurulan ikinci yöntem olduğu ifade edilmiştir. Bu iki yöntem toplam cevapların \%44,6'sını oluşturmaktadır.

Tablo 8: İşten Ayrılmaların Engellenmesi İçin Alınan Önlemler/Tedbirler

\begin{tabular}{|l|c|c|}
\hline \multicolumn{1}{|c|}{ Ayrılmaları önlemek için alınan önlemler } & Frekans & $\begin{array}{c}\text { Maddelerin } \\
\text { yüzdesi }\end{array}$ \\
\hline Motivasyon görüşmelerinin/toplantılarının yapılması & 12 & 25,5 \\
\hline Maaş düzenlemesi & 9 & 19,1 \\
\hline Eğitim/seminer/kurs verilmesi & 5 & 10,6 \\
\hline $\begin{array}{l}\text { Çalışma koşullarının iyileştirilmesi (çalışma saatlerinde ve } \\
\text { lojman şartlarında iyileştirme, intiyaç halinde ek izin vb.) }\end{array}$ & 4 & 8,5 \\
\hline Sosyal hakların korunması (Sigorta, izinler, vb.) & 4 & 8,5 \\
\hline $\begin{array}{l}\text { Personel için sosyal etkinlikler düzenlenmesi ya da personelin } \\
\text { sosyal etkinliklere katımasını sağlamak }\end{array}$ & 3 & 6,4 \\
\hline Mümkünse terfi verilmesi & 3 & 6,4 \\
\hline Personelin intiyacı doğrultusunda yardımlarda bulunmak & 2 & 4,3 \\
\hline Prim, ödül ya da ikramiye verilmesi & 2 & 4,3 \\
\hline $\begin{array}{l}\text { Samimi ve sıcak bir ortam yaratılarak aidiyet ve } \\
\text { rahatlık hissettirilmesi }\end{array}$ & 2 & 4,3 \\
\hline Başka işletmeye/şubeye transfer edilme imkanının sunulması & 1 & 2,1 \\
\hline Herhangi bir önlem almayan işletmeler & 15 & - \\
\hline
\end{tabular}


Çalışmanın sağladığı veriler yardımıyla Doğu Akdeniz Bölgesi'nde gerçekleşen işgücü devrinin oranı belirlenmiştir. Verilerden yola çıkarak Doğu Akdeniz'de yaşanan işgücü devri şu şekilde hesaplanmıştır;

İşgörenlerin devir oranı: [((537+609):2):2064)] x100 = \%27,8

Gerçekleşen işgücü devri \%27,8 olarak tespit edilmiştir. Bu oranın \%10,2'sini kadın işgörenler, geriye kalan \%17,6'sını ise erkek işgörenler oluşturmaktadır. Oranlardan da anlaşılacağı gibi erkek çalışanlarda daha fazla devrin yaşandığı görülmektedir. Erkek çalışanların, kadın çalışanların iki kati düzeyinde olduğu göz önünde bulundurulduğunda, bu durumun normal olduğu düşünülebilir.

Tablo 9: Cinsiyete Göre İşgören Devir Hızları

\begin{tabular}{|l|l|l|l|l|l|}
\hline Cinsiyete göre & $\begin{array}{l}\text { İşe alınan } \\
\text { (A) }\end{array}$ & $\begin{array}{l}\text { Işten } \\
\text { ayrılan (B) }\end{array}$ & $\begin{array}{l}\text { Alınan ve } \\
\text { ayrılanların } \\
\text { ortalaması (C) } \\
((\mathbf{A + B}) / \mathbf{2})\end{array}$ & $\begin{array}{l}\text { Ortalama } \\
\text { işgören } \\
\text { sayısı (D) }\end{array}$ & $\begin{array}{l}\text { Iş̧ören devir } \\
\text { oranı } \\
\left((\mathbf{C} / \mathbf{D})^{\star} \mathbf{1 0 0}\right)\end{array}$ \\
\hline Kadın & 201 & 219 & 210 & 2064 & 10,2 \\
\hline Erkek & 336 & 390 & 363 & 2064 & 17,6 \\
\hline Toplam & 537 & 609 & 573 & 2064 & 27,8 \\
\hline
\end{tabular}

Çalışan ortalamasına bakıldığında, Doğu Akdeniz Bölgesinde faaliyet gösteren otel işletmelerinde en çok çalışanın Adana ilinde, en az çalışanın ise Osmaniye ilinde olduğu görülmektedir. Tablo 10'daki veriler incelendiğinde en çok devrin yaşandığı şehir, \%35,3 ile Osmaniye'dir. Bunun sebebinin, çalışmaya bu ilden bir işletmenin katılması ve bu ilde işletme sayısının az olmasına karşın, işgücü arzının fazla olmasından kaynaklandığı düşünülmektedir.

En az devirin yaşandığı şehir ise Kahramanmaraş olarak tespit edilmiştir. Bu şehirde yaşanan işgücü devrinin \%7,7'sini kadınlar, \%15,2'sini ise erkekler oluşturmaktadır. Toplamda yaşanan işgücü devri ise \%22,9 düzeyindedir.

Literatürde yer alan bilgilere dayanarak, genel olarak işletmeler için yıllık \%13 \%14'lük devir oranı normal kabul edilmektedir. Bu devir oranından yüksek olan oranlar, yüksek devir hızı, düşük olan oranlar ise düşük devir hızı olarak değerlendirilmiştir (Korkusuz ve Halıcı, 2008; 296; Çakınberk, Derin ve Gün, 2010; 259). Bu bilgiye dayanarak, Doğu Akdeniz Bölgesinde ve bu bölgede yer alan illerde gerçekleşen devir oranının, kabul edilebilir seviyeden yüksek olduğu söylenebilir.

Tablo 10: Şehirlere Göre Personel Devir Hızı

\begin{tabular}{|l|c|c|c|c|c|}
\hline Şehirler & $\begin{array}{c}\text { İşe alınan } \\
(\mathbf{A})\end{array}$ & $\begin{array}{c}\text { işten ayrılan } \\
\mathbf{( B )}\end{array}$ & $\begin{array}{c}\text { Alınan ve ayrılanların } \\
\text { ortalaması(C) } \\
(\mathbf{( A + B ) / 2 )}\end{array}$ & $\begin{array}{c}\text { Ortalama işgören } \\
\text { sayısı (D) }\end{array}$ & $\begin{array}{c}\text { Işgören devir } \\
\text { oranı } \\
\left((\mathbf{C} / \mathbf{D})^{*} \mathbf{1 0 0}\right)\end{array}$ \\
\hline Mersin & 160 & 182 & 171 & 571 & 29,9 \\
\hline Adana & 249 & 273 & 261 & 1010 & 25,8 \\
\hline Hatay & 76 & 88 & 82 & 257 & 31,9 \\
\hline Osmaniye & 18 & 23 & 20,5 & 58 & 35,3 \\
\hline K.Maraş & 34 & 43 & 38,5 & 168 & 22,9 \\
\hline Toplam & 537 & 609 & 573 & 2064 & 27,8 \\
\hline
\end{tabular}


Işletmelerin yıldız sayıları baz alınarak hesaplandığında ise 4 yıldızlı işletmelerde nispeten daha fazla işgücü devri yaşandığı görülmektedir. 4 yıldızlı işletmelerde yaşanan devrin \%12'sini kadın işgörenler oluştururken, \%17'sini ise erkek işgörenler oluşturmaktadır. Buradan yola çıkarak, erkek işgörenlerde daha çok alımların ve ayrılmaların yaşandığı söylenilebilir. Toplamda ise 4 yıldızlı işletmelerde, $\% 29$ oranında işgücü devri gerçekleşmektedir.

Tablo 11: Yıldız Sayısına Göre İşten Ayrılma Oranları

\begin{tabular}{|l|c|c|c|c|c|}
\hline $\begin{array}{l}\text { Yıldıza } \\
\text { göre }\end{array}$ & $\begin{array}{c}\text { Işe alınan } \\
\text { (A) }\end{array}$ & $\begin{array}{c}\text { İşten } \\
\text { ayrılan } \\
\text { (B) }\end{array}$ & $\begin{array}{c}\text { Alınan ve } \\
\text { ayrılanların } \\
\text { ortalaması (C) } \\
((\mathbf{A}+\mathbf{B}) / 2)\end{array}$ & $\begin{array}{c}\text { Ortalama } \\
\text { işgören } \\
\text { sayısı (D) }\end{array}$ & $\begin{array}{c}\text { İşgören devir oranı } \\
\left((\mathbf{C} / \mathbf{D})^{*} \mathbf{1 0 0}\right)\end{array}$ \\
\hline 4 Yıldızlı & 285 & 319 & 302 & 1042 & 29,0 \\
\hline 5 Yıldızlı & 252 & 290 & 271 & 1022 & 26,5 \\
\hline Toplam & 537 & 609 & 573 & 2064 & 27,8 \\
\hline
\end{tabular}

Ayrılan işgörenlerin evli-bekar olmaları açısından incelendiğinde, işten ayrılan bekar işgörenlerin sayısının evlilerin iki buçuk katı olduğu görülmektedir. İşletmelerden ayrılan işgörenlerin \%72,4'ünü bekarlar ve \%27,6'sını ise evli olan işgörenler oluşturmaktadır. Oranlara bakarak bekar işgörenlerin evlilere göre işletmeden daha kolay ayrıldığını söylemek mümkündür. Bunun sebebinin, evli işgörenlerin bekarlara oranla daha fazla sorumluluk üstlenmesi olarak düşünülebilir.

Eğitim durumları incelendiğinde, ayrılan işgörenlerin yarıdan fazlasının $(53,4)$ lise mezunu ve üçte birinin ise (32) üniversite mezunu olduğu anlaşılmaktadır. Bu iki grup toplamda ayrılanların \%85,4'ünü oluşturmaktadır.

\section{Tablo 12: İşten Ayrılanların Eğitim Durumlarına Yönelik Bilgiler}

\begin{tabular}{|c|c|c|c|c|c|}
\hline Eğitim Durumu & $\begin{array}{l}\text { Isşten ayrılan } \\
\text { (A) }\end{array}$ & $\begin{array}{l}\text { Ayrılan } \\
\text { sayısı } \\
\text { (B) }\end{array}$ & Min. & Max. & $\begin{array}{l}\text { Yüzde } \\
\left((A / B)^{*} 100\right)\end{array}$ \\
\hline İlkokul Mezunu & 55 & 609 & 1 & 5 & 9,0 \\
\hline Ortaokul Mezunu & 30 & 609 & 1 & 4 & 4,9 \\
\hline Lise Mezunu & 325 & 609 & 1 & 27 & 53,4 \\
\hline Üniversite Mezunu & 195 & 609 & 1 & 11 & 32,0 \\
\hline Master/Doktora Mezunu & 4 & 609 & 1 & 2 & 0,7 \\
\hline Toplam & 609 & & & & 100,0 \\
\hline
\end{tabular}

Ayrılan çalışanların yaşları göz önüne alındığında, ayrılmaların en çok 18 ve 24 yaş aralığında gerçekleştiği görülmektedir. Sonrasında ise ağılıklı olarak, 25 ve 34 yaş aralığında olan işgörenlerin ayrıldığı göze çarpmaktadır. 18 ve 34 yaş arası ayrılan işgörenler, ayrılan toplam işgörenlerin \%87,4'ünü oluşturmaktadır.

Tablo 13: İşten Ayrılanların Yaşlarına Yönelik Bilgiler

\begin{tabular}{|l|c|c|c|c|c|}
\hline \multicolumn{1}{|c|}{ Medeni Durum } & $\begin{array}{c}\text { İşten } \\
\text { ayrılan (A) }\end{array}$ & $\begin{array}{c}\text { Ayrılan } \\
\text { sayısı (B) }\end{array}$ & Min. & Max. & $\begin{array}{c}\text { Yüzde } \\
\left((\mathbf{A} / \mathbf{B})^{*} \mathbf{1 0 0}\right)\end{array}$ \\
\hline 18 ve 24 yaş arası & 319 & 609 & 1 & 24 & 52,4 \\
\hline 25 ve 34 yaş arası & 213 & 609 & 1 & 13 & 35,0 \\
\hline 35 ve 44 yaş arası & 56 & 609 & 1 & 7 & 9,2 \\
\hline 45 yaş ve üzeri & 21 & 609 & 1 & 4 & 3,4 \\
\hline Toplam & 609 & & & & 100,0 \\
\hline
\end{tabular}


Tablo 14'de otel işletmelerinde yaşanan ayrılmaların, departman bazında gruplandırılmasına yönelik bulgulara yer verilmiştir. Elde edilen bulgulara göre, en fazla ayrılmanın yaşandığı departmanlar sırasıyla 211 kişiyle servis ve 174 kişiyle kat hizmetleri departmanlarıdır. Servis ve kat hizmetleri departmanlarından ayrılanlar, toplam ayrılanların yaklaşık üçte ikisini $(\% 63,2)$ oluşturmaktadır. En az ayrılmanın yaşandığı departmanlar ise insan kaynakları ve muhasebe departmanları olarak belirlenmiştir. Bu iki departmanın, diğer departmanlara göre daha az personel istihdam etmesi ve ofis çalışması yaptıkları için ayrılmalarında düşük olduğu düşünülmektedir. Detaylar Tablo 14'de yer almaktadır.

Tablo 14: İşten Ayrılanların Departmanlarına Yönelik Bilgiler

\begin{tabular}{|l|c|c|c|c|c|}
\hline Departmanlar & İşten ayrılan (A) & $\begin{array}{l}\text { Ayrılan sayısı } \\
(\mathbf{B})\end{array}$ & Min. & Max. & $\begin{array}{l}\text { Yüzde } \\
\left((\mathbf{A} / \mathbf{B})^{\star} \mathbf{1 0 0}\right)\end{array}$ \\
\hline Servis & 211 & 609 & 2 & 18 & 34,6 \\
\hline Kat Hizmetleri & 174 & 609 & 1 & 13 & 28,6 \\
\hline Önbüro & 89 & 609 & 1 & 5 & 14,6 \\
\hline Diğer Alanlar & 47 & 609 & 1 & 8 & 7,7 \\
\hline Mutfak & 45 & 609 & 1 & 4 & 7,4 \\
\hline Güvenlik & 16 & 609 & 1 & 2 & 2,6 \\
\hline Teknik Servis & 13 & 609 & 1 & 1 & 2,1 \\
\hline Muhasebe & 9 & 609 & 1 & 1 & 1,5 \\
\hline İnan Kaynakları & 5 & 609 & 1 & 2 & 0,8 \\
\hline Toplam & 609 & & & & 100,0 \\
\hline
\end{tabular}

Ayrılan işgörenlerin neredeyse tamamına yakınını, işçi pozisyonundaki personel oluşturmaktadır. Araştırmaya katılan 40 işletme, 2016 yılı içinde toplamda 609 işgörenin ayrıldığını, bunların 570'inin işçi pozisyonundaki personelin oluşturduğunu ifade etmiştir. Bu sayı toplam ayrılma oranının \%93,6'sını oluşturmaktadır. Ayrıntılar Tablo 15'de yer almaktadır.

Tablo 15: İşten Ayrılanların Mevkilerine Yönelik Bilgiler

\begin{tabular}{|l|c|c|c|c|c|}
\hline Mevkiler & $\begin{array}{l}\text { İşten } \\
\text { ayrılan (A) }\end{array}$ & $\begin{array}{l}\text { Ayrılan } \\
\text { sayısı (B) }\end{array}$ & Min. & Max. & $\begin{array}{l}\text { Yüzde } \\
\left.(\mathbf{( A / B})^{*} \mathbf{1 0 0}\right)\end{array}$ \\
\hline İşçi & 570 & 609 & 2 & 38 & 93,6 \\
\hline Departman şefi & 31 & 609 & 1 & 2 & 5,1 \\
\hline Departman müdürü & 6 & 609 & 1 & 1 & 1,0 \\
\hline Tepe yönetim & 2 & 609 & 1 & 1 & 0,3 \\
\hline Toplam & 609 & & & & 100,0 \\
\hline
\end{tabular}

Tablo 16'da görüldüğü gibi işgücü devrine sebep olan işgörenlerin büyük çoğunluğu, işletmede 6 aydan az bir süre çalışmıştır. İşletmeye alınan çalışanların $\% 56,2$ 'si çeşitli sebeplerden dolayı 6 aydan daha kısa bir sürede işletmeden ayrılmıştır. Tablo 16'da çalışma süreleri ile ilgili daha detaylı bilgiler yer almaktadır. 
Tablo 16: İşten Ayrılan İşgörenlerin İşletmedeki Çalışma Sürelerine Yönelik Bilgiler

\begin{tabular}{|l|c|c|c|c|c|}
\hline $\begin{array}{l}\text { Işletmedeki } \\
\text { çalışma süreleri }\end{array}$ & $\begin{array}{l}\text { Işten ayrılan } \\
\text { (A) }\end{array}$ & $\begin{array}{l}\text { Ayrılan } \\
\text { sayısı (B) }\end{array}$ & Min. & Max. & $\begin{array}{l}\text { Yüzde } \\
\left.(\mathbf{( A / B})^{*} \mathbf{1 0 0}\right)\end{array}$ \\
\hline 6 aydan az & 342 & 609 & 1 & 27 & 56,2 \\
\hline 6 ay 12 ay arası & 183 & 609 & 1 & 12 & 30,0 \\
\hline 13 ay 36 ay arası & 55 & 609 & 1 & 6 & 9,0 \\
\hline 37 ay 60 ay arası & 16 & 609 & 1 & 2 & 2,6 \\
\hline 61 ay ve üzeri & 13 & 609 & 1 & 3 & 2,1 \\
\hline Toplam & 609 & & & & 100,0 \\
\hline
\end{tabular}

\section{Sonuç ve Öneriler}

Bulgular, araştırmaya katılan otel işletmelerinin \%35'inde insan kaynakları planlaması yapıldığını göstermektedir. Kahramanmaraş ve Osmaniye'deki otel işletmeleri diğer illere kıyasla insan kaynakları plânlamasına daha az önem vermektedir. Çünkü bu iki şehirde hiçbir işletme insan kaynakları planlaması yapmamaktadır. Bu durumun birkaç nedeni olabilir. Öncelikle bu iki şehirdeki işletmeler tüm yıl hizmet verdiği için sezonluk yoğunlaşma söz konusu değildir. Bundan dolayı da işletmeler işgörenleri işletmede tutmak için ekstra bir çaba sarf etmeyebilirler. Diğer bir sebep de bu şehirlerde faaliyet gösteren işletmelerin çalışan sayısı nispeten daha azdır ve buna bağlı olarak toplam ayrılan ve işe alınan personel sayısı da azdır. Bu durum, işletmelerin insan kaynakları planlamasını bir zorunluluk olarak görmemelerine neden olmuş olabilir. Hâlbuki tüm yıl faaliyette olan otel işletmeleri, bünyesindeki işgörenlerin yetenek ve bilgilerini geliştirerek işgörenlerden daha fazla yarar sağlayabilir. Onları işletmede tutmaya yönelik faaliyetlerde bulunarak, bu bilgi ve beceri birikiminin rakip işletmelere gitmesinin önüne geçebilir. Aynı zamanda yaşanan işgücü devrini minimuma indirebilir. Bunların yapılması ise ancak etkin bir insan kaynakları plânlaması ile mümkündür.

Işletmelerin yarıdan fazlasının $(\% 57,5)$ yaşanan işgücü devrini her zaman dikkate aldığını belirtmesine karşın işletmelerin çoğunluğunun $(\% 71,2)$ geçmiş yıllarda yaşanan işgücü devrinin oranını hesaplamadığı görülmüştür. İşletmelerin sadece 10'u, önceki yıllarda işgücü devir oranını hesaplamıştır. İşgören devir oranının hesaplanması ve değerlendirmenin işletmelerin insan kaynakları plânlamaları içerisine dahil edilmesi, işletmelerin yeteri kadar önem verilmeyen bir gider kaynağını azaltmasını sağlayabilir. Ek olarak, işletmelerin işgören devir oranını insan kaynakları plânlamasına dahil etmeleri, ilerleyen dönemlerde oluşabilecek işgören devrine karşı bilinçli ve tedbirli olmalarına da yardımcı olabilir.

Doğu Akdeniz Bölgesi'nde gerçekleşen işgücü devri \%27,8 olarak tespit edilmiş ve bu oranın çoğunluğunu erkek işgörenler oluşturduğu belirlenmiştir. En çok işten ayrılmaların ve işe alımların Osmaniye ilinde gerçekleştiği belirlenmiştir. Ancak Osmaniye ilinden çalışmaya yalnızca 1 işletmenin katıldığı göz önünde bulundurulursa, bu sonuç yanıltıcı olabilir. Osmaniye'den sonra işgücü devri en çok Mersin ilinde gerçekleşmiştir. Bunun sebebinin, Mersin ilinde birçok sezonluk otel bulunmasından dolayı, sezonda yaşanan yoğunluğun, şehir otellerini de etkileyebileceği ve ayni zamanda, üniversitenin şehir merkezinde yer almasından dolayı, öğrencilerin istihdam edilmesinden de kaynaklanabileceği düşünülmektedir.

Doğu Akdeniz Bölgesinde yaşanan işgücünün devri diğer çalışmalarla karşılaştırıldığında, Aksu'nun, 1995 yılında Antalya'da yaptığı çalışmada işgücü devir oranının \%39 olduğu tespit edilmiştir fakat 2010 yılında Bozkurt tarafından yine 
Antalya'da yapılan çalışmada bu oran \%67,02 olarak belirlenmiştir. Bu iki araştırmanın sonuçlarının dikkat çekici şekilde farklı olması, turizm sektöründeki çalışma koşulları ile makro çevresel faktörlerde değişimlerle ilişkilendirilmesi mümkündür. Güzel (2002) ise işgücü devir hızının, Kuşadası'nda \% 40-50, İzmir merkezde \%10-20 düzeyinde olduğu bulgusuna ulaşmıştır. Diğer çalışmalarda ise oranlar, Muğla'da \% 49,79 (Demir, 2002), Ankara'da \% 34 (Tuna, 2007), Kapadokya bölgesinde yer alan turizm merkezlerinin genel ortalaması \%46,8 (Gün, 2008) ve Avusturya'da çalışanlar için \%50,74 ve idari personel için \%39,19 (Davidson, Timo ve Wang, 2010) düzeyinde olduğunu tespit edilmiştir. Genel olarak bakıldığında, Doğu Akdeniz Bölgesinde yer alan illerde gerçeklesen işgücü devrinin İzmir merkez (\%10-20) dışındaki sonuçlardan daha düşük olduğu görülmüştür.

Yıldız bazında incelendiğinde 4 yıldızlı otel işletmelerinde, 5 yıldızı işletmelere oranla daha fazla işgücü devri yaşandığı görülmektedir. 4 yıldızlı işletmelerin genel olarak insan kaynakları planlaması yapmadığı ve önceki yıllarda personel devir oranını hesaplamadığı görülmüştür. Buradan yola çıkarak 4 yıldızıı işletmelerin, 5 yıldızlı işletmelere oranla personel devir oranına çok önem vermediği söylenebilir.

Tüm işletmelerde, erkek çalışanlar kadın çalışanlara kıyasla daha fazla istihdam edilmektedir. Ayrıca bekar bireylerin de, evli bireylere göre çalışma oranı $2 / 3$ düzeyindedir. Bu yapının oluşmasında, bölge insanının kültürel yapısının ve otel algısının rol oynadığı düşünülmektedir. Bunu destekler nitelikte, bazı yöneticiler bünyelerindeki kadın personelin, evlendikten sonra ya da akşam vardiyasına geçince işletmeye devam etmeme kararı aldıklarını belirtmiştir. Bu durum bazı işletmelerde işgücü devrini arttırmaktadır.

Eğitim durumları incelendiğinde, ayrılan işgörenlerin \%85,4'ünün lise ve üniversite mezunu olduğu anlaşılmaktadır. Bu sonuçlar, Doğu Akdeniz Bölgesinde faaliyet gösteren şehir otellerinde personelinin 3/4'ten fazlasının lise ve üzeri bir eğitim seviyesine sahip olduğunu gösterir. Ayrıca ayrılanların büyük çoğunluğunun lise ve üniversite mezunu olmaları nedeniyle bu yönde herhangi soru sorulmamış olmasına rağmen eğitim seviyesi arttıkça ayrılmalarında arttığı düşünülebilir. Diğer taraftan bu düşünce gerçeği yansıtmayabilir. Çünkü konaklama sektöründeki eğitim seviyesi yıllar içinde artış göstermiştir ve artık konaklama sektöründe geçmiş yıllara oranla daha az ilkokul ve ortaokul mezunu işgören bulunmaktadır. Konuyla ilgili daha önce yapılmış olan araştırmalar da bu durumu destekler niteliktedir. Kültür ve Turizm Bakanlığı tarafından 1993 yılında yapılan "Turizm endüstrisi işgücü araştırması" sonuçlarına göre turizm sektöründe, konaklama alanında istihdam edilen personelin \%41'i ilkokul, \%16'si ortaokul, \%46'si lise ve \%11'i de üniversite mezunudur. Sonrasında 2014 yılında yapılan başka bir araştırma sonuçları ise şu şekildedir. Konaklama sektöründe çalışanların \%29,1'i ilkokul, \%27,1'i ortaokul, \%27,3'ulise mezunu ve \%15,5'i üniversite mezunu olarak belirtilmiştir (Kılıç, 2014). Araştırma sonuçları incelendiğinde yıllar içinde konaklama sektöründe eğitim seviyesinin arttığını söylemek mümkündür.

Ayrılan işgörenlerin demografik özellikleri incelendiğinde; ayrılan işgörenlerin ezici çoğunluğunu 18-34 yaş arası işgörenler oluşturmaktadır. En az ayrılma oranı ise 45 yaş ve üzerinde gerçekleşmiştir. 35 yaş ve üzeri yaşlarda ayrılma oranlarının düştüğü gözlemlenmektedir. Bunun sebebinin, genç çalışanların genellikle işini geçici olarak düşünmesi, 35 yaş ve üzeri çalışanların ise artık evlenip düzenli bir iş hayatına sahip olmak istemesi olduğu düşünülmektedir.

En çok ayrılmaların yaşandığı departmanlar servis ve kat hizmetleri olarak belirlenmiştir. Bunun sebebinin, bu iki departmanda diğer departmanlara oranla daha 
fazla personel istihdam edilmesi ve bu istihdam sayısına bağlı olarak da ayrılmaların daha fazla olduğu düşünülmektedir. Ayrıca Örücü ve Şahin'in (2001: 20) bulgularına göre otel işletmelerinde istihdam edilecek personel bulmanın güç olduğu departmanlar servis departmanı, önbüro, kat hizmetleri ve mutfaktır. Personel bulmanın güç olmasının sebeplerine yönelik olarak, turizm eğitimi alan öğrencilerin sektörde çalışma eğilimini konu alan bazı çalışmalar referans gösterilebilir. Yapılan bu çalışmalarda, öğrencilerin başlangıçta turizm sektöründe çalışmaya karşı olumlu bir tutuma sahip olduklarını fakat sektörün çalışma koşullarını yakından gördüklerinde çalışma isteklerinin törpülenerek sektörden uzaklaştıklarını ifade etmiştir. Ayrıca turizm sektöründe ücret ve ek gelirlerin düşüklüğü, terfi imkanları ve sektörde çalışmanın sağlayacağı sosyal statünün düşük olduğu ve çalışma şartlarının ağır oluşu gibi dezavantajlarının, avantajlarından daha fazla olduğu ve ilerleyen yıllarda başka sektörlere yönelme eğiliminde oldukları da öğrencilerin ifadeleri arasında yer almıştır (Duman, Tepeci ve Unur, 2006; Türker, Uçar ve Ateş, 2016; Köşker ve Unur, 2017).

İnsan ilişkilerinin yoğun yaşandığı önbüro, servis ve kat hizmetleri departmanlarında iş temposu da yoğun olduğu için işgörenler stres altında çalışmaktadır (Güzel, 2002). Özellikle bu departmanlarda yaşanan ayrılmalara yönelik önlemler alınması, işletmelerde yaşanan işgücü devrini önemli ölçüde azaltacağı varsayılabilir.

Işletmeye alınan çalışanların \%56,2'si çeşitli sebeplerden dolayı 6 aydan daha kısa bir sürede işletmeden ayrılmıştır. Bu ayrılmalarda, işgörenin işletmeye alışma sürecinde yaşadıkları sıkıntıların ve işgörenin gösterdiği performansın önemli rol oynadığı düşünülmektedir. Ayrıca araştırmanın yapıldığı dönem itibariyle Türkiye'nin içinde bulunduğu ekonomik ve siyasi durumlarla, yaşanan olayların da ayrılmalara etkisi olduğu düşünülmektedir. 12 aydan az süre çalışıp ayrılanlar, toplam ayrılanların $\% 86,2$ 'sini yani 3/4'ten fazlasını oluşturmaktadır. Veriler incelendiğinde personelin çalışma süreleri ile ayrılma oranlarının ters orantılı olduğu görülmektedir. Çalışma süresi arttıkça, işletmeden ayrılmaların azaldığı, 3 yıl ve üzeri çalışanların ayrılma oranlarının en düşük olduğu görülmektedir. Bu bulgulara dayanarak, işletmelerde çalışma süresi arttıkça işletmeye bağlıı̆̆ın arttığını söylemek mümkündür. Nitekim Ezeuduji ve Mbane'nin (2017) gerçekleştirdiği çalışmada bu görüşü destekler niteliktedir.

Araştırmaya katılan yöneticilerin neredeyse yarısı, geçen yıllara kıyasla 2016 yılındaki işgücü devrinde artış yaşandığını belirtmiştir. Yöneticiler bunun sebeplerini, ülkede yaşanan terör olayları ve patlamalar, Rusya ile yaşanan uçak krizi, 15 Temmuz darbe girişimi ve ülkede yaşanan ekonomik kriz şeklinde sıralamıştır. Ayrıca müdahale edilemeyen ayrılmalarda da, ülkede yaşanan ekonomik krizler ilk sırada yer almaktadır. Bahsi geçen bu olaylar nedeniyle ülkeye gelen turist ve iş adamı sayılarında ciddi azalmalar olduğu, bundan dolayı da mevcut personelde azaltmaya gidildiği ya da tekrardan maaş düzenlemesi yapıldığı yine ifadeler arasındadır. Söz konusu değişkenlere yönelik bireysel bazda yöneticilerin ya da sektörün bütün olarak önlem alması pek mümkün görünmemektedir. Bu konuda merkezi yönetimin ve toplumun bir bütün olarak önlem almaya çalışması ve hatta diğer ulusların ve uluslararası örgütlerin de mücadelenin içine çekilmesi gerekir.

İsgörenlerin kendi istekleri ile işletmeden ayrılmalarında etkili olan temel faktör işgörenin aldığı ücreti yetersiz görmesidir. Bu bulgudan yola çıkarak, işgörene aynı şartlar sunulduğunda işgören, daha yüksek ücret veren işyerini tercih edecektir. Özellikle ekonomik kriz dönemlerinde, işgörene piyasa düzeyinde veya piyasanın 
üzerinde ücret verilmesi, işgörenin işletmede kalmasında ücret faktörünün etki derecesini arttırabilir.

Görüşülen işletme yöneticileri, ayrılan ve işe yeni alınan işgörenlerin işletmeye yüklediği maliyetler konusunda, en çok maliyet oluşturan kalemin, kıdem tazminatı olduğunu ifade etmişlerdir. Oysaki kıdem tazminatının maliyeti, toplam işgücü maliyetinin yalnızca \% 4,4'ü kadardır. Türkiye İşveren Sendikaları Konfederasyonu'nun (TiSK) her yıl yayımladığı Çalışma İstatistikleri ve İşgücü Maliyeti istatistiklerinde, kıdem tazminatının, toplam işgücü maliyetinde \% 35'lik payı olan sosyal ödemeler içinde yer aldığını belirtmiştir (TiSK, 2017). Yani diğer bir deyişle, kıdem tazminatının işletmelere ekstradan çok bir maliyet yüklemediği düşünülmektedir.

Sonuç olarak Doğu Akdeniz Bölgesinde yaşanan işgücü devri, ortalama olarak diğer çalışma yapılan şehirlerde yaşanan işgücü devrine yakın, fakat onlardan bir nebze daha düşük olarak tespit edilmiştir. Buradaki farkın, bu çalışmaya Mersin dışında sezonluk işletmelerin dahil edilmemesinden kaynaklanabileceği düşünülmektir. Bu çalışmada elde edilen sonuç, Ankara ve İzmir'de ulaşılan oranlara yakın çıkmıştır. Diğer çalışmaların yapıldığı Antalya, Kapadokya Bölgesi, Kuşadası ve Muğla gibi yerler daha çok turistik yerler olduğu için devir oranının daha yüksek çıktığı söylenilebilir.

Alanyazına göre, genel olarak işletmeler için \%13-\%14 düzeyindeki işgören devir oranı normal kabul edilmektedir. Bu devir oranından yüksek olan oranlar, yüksek devir hızı, düşük olan oranlar ise düşük devir hızı olarak değerlendirilmektedir (Korkusuz ve Halıcı, 2008; Çakınberk, Derin ve Gün, 2010). Bu bilgiden yola çıkarak değerlendirildiğinde, yüksek oranda bir işgücü devri gerçekleştiği ve bu oranı düşürmek için ise işletmelerin motivasyon görüşmeleri ve maaş düzenlemeleri gibi önlemler aldığı görülmüştür. Bu önlemlere ek olarak, işletmelere aşağıdaki önlemleri almaları önerilebilir.

Bir işgören işe alındığında, ona oryantasyon ve eğitim programı sunulması gerekir. Sunulmadığında, işgören sorumlu olduğu konuları ve görevlerini tam olarak anlayamayabilir ve işi yapma sürecinde sıkıntılar çekebilir, sonuç olarak da kısa süre içerisinde işletmeden ayrılabilir. Bunun önüne geçebilmek için hem işletmenin işgöreni tanıması hem de işgörenin işletmeyi tanıması amacıyla belli bir süreye (bireysel sözleşmeler için en fazla 2 ay, toplu iş sözleşmeleri için en fazla 4 ay) deneme süresi olarak sözleşmede yer verilebilir (IŞKUR, 2003). Bu süre zarfında, işe alınması planlanan bireyin deneyim, bilgi ve becerileri değerlendirilebilir. Ayrıca işletmeler başvuruları değerlendirirken başvuran hakkında detaylı bir deneyim kontrolü yapabilir, bir önceki işyerinden ayrılma sebebini araştırabilir. Bu sayede başvuru sahibinin işletmeden beklentileri ve varsa bireyin sorunları hakkında önceden bilgi sahibi olunabilir. Ayrıca, ayrılan personelin ayrılma sebepleri öğrenilmeli ve buna göre önlemler alınmalıdır. Ayrılma sebepleri, kalan çalışanlara da detaylı şekilde açıklanırsa, çalışanlar örgüt kültürü hakkında daha detaylı bilgi sahibi olabilir. Böyle bir yaklaşımla ve çalışan seçimiyle, yaşanan işgücü devri azaltılabilir. Genç işgörenlere, işletmede kariyer imkanları sunarak işletmeye daha bağlı hale getirilebilir. İşgörenlere yönelik sosyal aktiviteler de bu devri azaltma konusunda faydalı olabilir. Personel günleri, partiler, piknikler, iş yemekleri, işgörenler arasında veya işletmeler arasında spor müsabakaları düzenlemek ve hatta genç işgörenlere yönelik eğitim bursları temin etmek bu aktiviteler arasında sayılabilir.

Turizmde yüksek işgücü devri yaşandığını belirten çalışmalara dayanarak, ayrılan işgörenlerin, turizm sektöründe gerekli olan deneyimi kazanamamış ve sektörün gereklerini ve zorluklarını tam manasıyla öğrenememiş oldukları 
söylenebileceği gibi sektörün işgörenlere hala yeterli ücreti vermediği ve işgörenlerin işte kalmalarını sağlayacak ortamı oluşturmadığı da söylenebilir. Ayrıca işgören devir hızının yüksekliği yöneticilerin yeterli önlemi almamasından da kaynaklanabilir. Bunun nedeni de yöneticilerin yeterli deneyim ve birikime sahip olmamaları olabilir. İşletmelerin işgören devrinden gördükleri zararı en aza indirmek amacıyla, işletmenin idari bölümlerine daha deneyimli ve turizmde uzun zamandır çalışan işgörenleri istihdam etmeleri önerilebilir. Sektörde daha kısa süredir çalışan işgörenleri ise idari olmayan veya daha alt kademedeki idari pozisyonlarda istihdam etmek daha verimli bir yönetim sistemi oluşturabilir.

İşörenlerin daha yüksek ücret veren işletmeleri tercih etmeleri, tahmin edilebilir bir durumdur. Aynı zamanda, işletmelerin çoğunluğunun satışların azaldığı ve ekonomik kriz yaşandığı dönemlerde, işten çıkarmalar gerçekleştirdiği bilinmektedir. Bu dönemlerde işgücü devrini azaltmak adına işletmeler, satışların azaldığı dönemlerde, işgörenlerle konuşup isten çıkarmak yerine ücretlerinde kesinti yapmayı teklif edebilir ve işletmede kalmalarını sağlayabilirler.

Araştırmanın Uygulama alanı Doğu Akdeniz Bölgesi'nde faaliyet gösteren dört ve beş yıldızlı şehir otelleri olarak belirlenmiştir. Ayrıca, çalışmaya katılan otel işletmelerinden ayrılan işgörenlerin bulunması ve ayrılma nedenlerine yönelik verilerin elde edilmesinin imkansız olması nedeniyle, anket soruları ilgili yöneticilere sorulmuştur. $\mathrm{Bu}$ durumlar araştırmanın temel sınırlııklarını oluşturmaktadır. Gelecekteki çalışmalarda, örneklem sayısı ve alanı daha geniş olan farklı bölgelerde yer alan işletmeler ele alınabilir. Hatta şehir otelleri ve mevsimlik oteller, diğer yıldız sayılarına sahip oteller ya da departmanlar arasında işgücü devir oranı karşılaştırması yapılabilir. Ayrıca, ayrılma nedenlerine yönelik cevapları sadece yöneticilerden toplamak yerine, işgörenleri de dahil ederek bu sınırılıklar ortadan kaldırılabilir.

\section{Kaynakça}

Akbulut, M. T., (2008), Özel Sağlık Kuruluşlarının işgücü Hareketliliği ve İşgücü Devir Oranını Etkileyen Faktörler,Yayınlanmamış Yüksek Lisans Tezi, Gazi Üniversitesi, Sosyal Bilimler Enstitüsü, Ankara.

Akova, O., Tanrıverdi, H., ve Kahraman, O. C., (2015). Otel İşletmelerinde İşgören Devir Hızına Etki Eden Risk Faktörlerinin Belirlenmesine Yönelik Bir Araştırma, Süleyman Demirel Üniversitesi Vizyoner Dergisi, 6(12), ss. 87-107.

Aksu, A. (1995). Otel İşletmelerinde İşgören Devir Hızının Verimlilikle Olan İlişkisinin Değerlendirilmesi ve Antalya Yöresi'nde Bir Uygulama. Yayınlanmamış Yüksek Lisans Tezi, Akdeniz Üniversitesi, Sosyal Bilimler Enstitüsü, Antalya.

Bozkurt H., (2010), Konaklama İşletmelerinde İnsan Kaynakları Yönetimi Kapsamında İşgören Devrinin ve işgören Devir maliyetlerinin Hesaplanması: Antalya Yöresinde Beş Yıldızlı Otellerde Bir Araştırma, Yayınlanmamış Yüksek Lisans Tezi, Akdeniz Üniversitesi, Sosyal Bilimler Enstitüsü, Antalya.

Chalkiti, K., ve Sigala, M, (2010), Staff Turnover İn The Greek Tourism İndustry: A Comparison Between İnsular And Peninsular Regions, International journal of contemporary hospitality management, 22(3), pp. 335-359.

Choi, Y., ve Dickson, D.R, (2009), A Case Study İnto The Benefits Of Management Training Programs: Impacts On Hotel Employee Turnover And Satisfaction Level, Journal of Human Resources in Hospitality \& Tourism, 9(1), pp. 103-116.

Çalışma ve Sosyal Güvenlik Bakanlığı, 2016 Ocak Ayı İstatistikleri, (2019), https://www.ailevecalisma.gov.tr/media/1241/2016-ocak-ayi-is-koluistatistikleri.pdf (09-04-2019). 
Çalışma ve Sosyal Güvenlik Bakanlığı (CSGB), (2017), https://www.csgb.gov.tr/home/contents/sendikalar/isciisveren/ (04-04-2017).

Çakınberk, A., Derin, N., ve Gün, G. (2010). Otel İşletmelerinde İnsan Kaynakları Açısından İşgören Devir Hızının Analizi: Kapadokya Bölgesi Örneği. Elektronik Sosyal Bilimler Dergisi, 10,ss. 252-272.

Davidson, M. C., Timo, N., ve Wang, Y. (2010). How much does labour turnover cost? A case study of Australian four-and five-star hotels. International Journal of Contemporary Hospitality Management, 22(4), 451-466.

DeMarco, T., ve Lister, T. (1987). Peopleware. Productive Projects and Teams. New York: Dorset House Publishing Co.

Demir, M., (2002), Konaklama İşletmelerinde İnsan Kaynakları Kapsamında İsgücü Devir Hızının Analizi; Muğla Bölgesi Örneği, Yayınlanmamış Yüksek lisans tezi, Dokuz Eylül Üniversitesi, Sosyal Bilimler Enstitüsü, İzmir.

Duman, T., Tepeci, M. ve Unur, K., (2006), Mersin'de Yükseköğretim Ve Orta Öğretim Düzeyinde Turizm Eğitimi Almakta Olan Öğrencilerin Sektörün Çalışma Koşullarını Algılamaları Ve Sektördeçalışma İsteklerinin Karşılaştırmalı Analizi, Anatolia: Turizm Araştırmaları Dergisi, 17(1), ss. 51-69.

Dusek, G. A., Clarke, R., Yurova, Y., ve Ruppel, C. P., (2016), Employee Turnover İn International Brand Hotels In Russia: A Comparison Of Nationals And Foreign Nationals, Journal of East-West Business, 22(1), pp. 51-75.

Erbil, S., (2013), Otel İşletmelerinde Çalışanların Örgütsel Sinizm Algılarının İşten Ayrılma Niyetine Etkisi, Yayınlanmamış Yüksek Lisans Tezi, Adnan Menderes Üniversitesi, sosyal Bilimler Enstitüsü, Aydın.

Ezeuduji, I. O., ve Mbane, T. L., (2017), Length of Service versus Employee Retention Factors: Hotels in Cape Town, South Africa, Acta Universitatis Danubius. Economica, 13(2).

Gün, G., (2008), Konaklama İşletmelerinde İşgören Devir Hızının Personel Motivasyonuna Etkisini Belirlemeye Yönelik Kapadokya Bölgesinde Bir Araştırma, Yayınlanmamış Yüksek Lisans Tezi, Düzce Üniversitesi, Sosyal Bilimler Enstitüsü, Düzce.

Güzel, B., (2002), Otel İşletmelerinde İşgören Devrinin Nedenleri: Kuşadası ve İzmir'deki Dört ve Beş Yıldızı Otel İşletmelerinde Bir Alan Araştırması. Yayınlanmamış Yüksek Lisans Tezi, Adnan Menderes Üniversitesi, Sosyal Bilimler Enstitüsü, Aydın.

Halis, M., ve Çamlıbel, Z., (2011), Algılanan iş güçlüğü iş değiştirme niyeti üzerindeki etkisi ve otel işletmelerinde bir araştırma. Reforma, 4(52), 75-84.

iŞKUR,2003,http://www.iskur.gov.tr./0/dokumanlar/kurumsal\%20bilgi/mevzuat/kanunla r/\%C4\%B0\%C5\%9F\%20Kanunu.pdf (15-04-2018).

Kaynak, T. (1990). Personel Planlaması. İstanbul: İşletme İktisadi Enstitü Yayınları.

Kazak, P., (2012), İşletmelerde Personel Devrinin Nedenleri ve işgörenlerin Eğitim Düzeyi ile İlişkisi: Denizli'deki Bir İşletmede Ampirik Bir Araştırma. Yayınlanmamış Yüksek Lisans Tezi, Pamukkale Üniversitesi, Sosyal Bilimler Enstitüsü, Denizli.

Kılıç, Y. (2014). Turizm Sektörü İstihdamının Eğitim Durumu Ve İnsan Gücü Planlaması, Eğitim Bilimleri Araştırmaları Dergisi, 4, ss. 419-436.

Korkusuz, B. ve Halıcı, A., (2008), İşgücü Devir Hızını Etkileyen Etmenler: Sekreterlik Mesleğinde Bir Araştırma. 7. Ulusal Büro Yönetimi ve Sekreterlik Kongresi, Karadeniz Teknik Üniversitesi, Trabzon, 291-301.

Köşker, H., ve Unur, K. (2017). Turizm Lisans Öğrencilerinin Turizm Sektöründe Çalışma Eğilimleri Üzerine Bir Araştırma. Seyahat ve Otel Iş̧/etmeciliği Dergisi, 14(2), ss.126-141.

Ongori, H. (2007). A review of the literature on employee turnover. 25 Şubat 2018 tarihinde 
http://www.academicjournals.org/AJBM/PDF/Pdf2007/Jun/Ongori.pdf

adresinden ulaşılmıştır.

Örücü, E. ve Şahin, O. (2001). Otel İşletmelerinde İnsan Kaynaklarına Yönelik Uygulamalar; Marmaris ve İçmeler Örneği. İktisat, Işletme ve Finans Dergisi, Temmuz 2001, ss. $18-24$.

Özler, H., Özler, N. D. E., ve Gümüştekin, G. E., (2007), Aile işletmelerinde nepotizmin gelişme evreleri ve kurumsallaşma. Selçuk Üniversitesi Sosyal Bilimler Enstitüsü Dergisi. (17), 437 - 450.

Pearson, R., (1991), The Human Resource, England: Mcgraw Hill Inc.

Pizam, A., ve Thornburg, S. W., (2000), Absenteeism And Voluntary Turnover In Central Florida Hotels: A Pilot Study, International Journal of Hospitality Management, 19(2), pp. 211-217.

Salha, H., (2012), İ̧̧ Güçlüklerinin İşgören Devir Hızına Etkisi: Yiyecek İçecek İşletmeleri Üzerine Bir Araştırmaa. Yayınlanmamış Yüksek lisans tezi, Sakarya Üniversitesi, Sosyal Bilimler Enstitüsü, Sakarya.

Sarıoğlan, M., (2007), Dört ve Beş Yıldızlı Otel İşletmelerinin Yiyecek İçecek Departmanlarında İşgören Devir Hızı: Çeşme Yöresinde Bir Uygulama, Yayınlanmamış Yüksek lisans Tezi, Balıkesir üniversitesi, Sosyal Bilimler Enstitüsü, Balıkesir.

Saltık, Z., (2016), Stresin İşgören Performansına ve İşten Ayrılma Niyetine Etkisi: Konaklama İşletmelerinde Bir Uygulama, Yayınlanmamış Yüksek Lisans Tezi, Hacı Bektaşi Veli Üniversitesi, Sosyal Bilimler Enstitüsü, Nevşehir.

Tiritoğlu, E., (2006), Konaklama İşletmelerinde Stres Faktörlerinin İşören Devir Hızına Etkisi Üzerine Bir Alan Araştırması, Yayınlanmamış Yüksek Lisans Tezi, Sakarya Üniversitesi, Sosyal Bilimler Enstitüsü, Sakarya.

Tuna, M., (2007), Personel Devir Oranı Analizi: Ankara'da Yer Alan Yıldızlı Otel İşletmelerinde Bir Uygulama. Anatolia: Turizm Araştırmaları Dergisi, 18(1), 4552.

Türkiye İşveren Sendikaları Konfederasyonu. (2017), 2015 Yılı Çalışma İstatistikleri Ve İşgücü Maliyetinin TISK Araştırma Servisince Değerlendirilmesi, http://tisk.org.tr/project/2015-calisma-istatistikleri-ve-isgucu-maliyeti// (16-072018).

Türker, N., Uçar, M. ve Ateş, M.A., (2016). Turizm Eğitimi Alan Öğrencilerin Turizm Sektörü Algıları: Karabük Üniversitesi Öğrencileri Üzerine Bir Araştırma. Karabük Üniversitesi Sosyal Bilimler Enstitüsü Dergisi, 6(2), ss. 311333.

Yang, J. T., Wan, C. S., ve Fu, Y. J. (2012). Qualitative examination of employee turnover and retention strategies in international tourist hotels in Taiwan. International Journal of Hospitality Management, 31(3), pp. 837-848.

Walmsley, A. (2004), Assessing Staff Turnover: A View From The English Riviera, International Journal of Tourism Research, 6(4), pp. 275-287. 